\title{
POLITIČKA DJELATNOST ANTE PARADŽIKA
}

\section{Velimir Veselinović}

Fakultet političkih znanosti

Sveučilišta u Zagrebu

E-mail: veselinovic.velimir@gmail.com

DOI: 10.20901/an.12.09

Prethodno priopćenje

Primljeno: veljača 2016.

\begin{abstract}
Sažetak Autor na temelju arhivske građe, tiska i relevantne literature rekonstruira život i političko djelovanje političara pravaške orijentacije Ante Paradžika. Za vrijeme Hrvatskog proljeća Paradžik je izabran za predsjednika Saveza studenata Hrvatske koji je okupljao predstavnike svih hrvatskih sveučilišnih centara. Kao jedan od predvodnika studentskog pokreta iz 1971. osuđen je na tri godine zatvora koje je u cijelosti izdržao. Uspostavom višestranačja u Hrvatskoj, Paradžik je bio obnovitelj i dopredsjednik Hrvatske stranke prava, a glavni politički cilj stranke bio je samostalna država Hrvatska. Izbijanjem agresije na Hrvatsku, Paradžik je zajedno s Dobroslavom Paragom organizirao dragovoljačke stranačke paravojne postrojbe nazvane Hrvatske obrambene snage. Bio je i dopredsjednik Hrvatskog demokratskog kluba za središnju Europu i glavni tajnik Hrvatskog društva političkih zatvorenika. Ubijen je 1991. pod nerazjašnjenim okolnostima od strane pripadnika hrvatske policije.
\end{abstract}

Ključne riječi Ante Paradžik, Hrvatsko proljeće, Hrvatska stranka prava, Hrvatske obrambene snage, suvremena hrvatska politička povijest

Uvod

Predmet ovog rada je rekonstrukcija života i političke djelatnosti Ante Paradžika, političara pravaške orijentacije, početkom sedamdesetih godina za vrijeme trajanja Hrvatskog proljeća i početkom devedesetih godina 20. stoljeća prilikom uspostave višestranačja u Hrvatskoj. Polazni motivi za znanstveno istraživanje ove teme su u činjenici da se u hrvatskoj politologiji i historiografiji do sada nitko sustavnije nije bavio ulogom koju je imao Paradžik u suvremenoj političkoj povijesti. Stoga je u fokusu ovoga rada upravo njegovo djelovanje, koje ima svoj značaj za potpunije upoznavanje događaja na široj javnoj sceni. Na ovaj način želim pridonijeti osvjetljavanju Paradžikove uloge i potaknuti na istraživanje drugih aktera iz različitih stranaka tog vremena. Rad je podijeljen u tri dijela: u prvom se prikazuje uloga Paradžika u Hrvatskom proljeću, drugi dio odnosi se na Paradžikove aktivnosti nakon uspostave višestranačja u Hrvatskoj, osobito u Hrvatskoj stranci prava (HSP), a treći, posljednji dio problematizira smrtonosni atentat na njega. 


\section{Životopis i Hrvatsko proljeće}

Ante Paradžik rođen je 10. veljače 1943. u mjestu Pregrađe, općina Ljubuški, Bosna i Hercegovina ( $\mathrm{BiH})$ od majke Milice rođene Mlinarević i oca Blaža, pripadnika oružanih snaga Nezavisne Države Hrvatske (NDH) kojem se svaki trag gubi 1945. na Bleiburgu, odnosno Križnom putu. U Ljubuškom je završio osnovnu i srednju školu. Nakon toga je otišao u Split gdje je upisao Pravni fakultet Sveučilišta u Splitu, a zatim nastavlja studij prava u Zagrebu. Kako je potjecao iz siromašne obitelji, povremeno je preko ljeta radio kao fizički radnik u Njemačkoj i Vojvodini. Sudjelovao je na omladinskim radnim akcijama na kojima je tri puta proglašen udarnikom (Kolašin, Vranj i Vrč). Za vrijeme Paradžikova studiranja politička zbivanja u Socijalističkoj Federativnoj Republici Jugoslaviji (SFRJ) bila su itekako burna: 1966. dogodio se pad Aleksandra Rankovića, koji je doživljen u hrvatskoj javnosti s izrazitim olakšanjem i nadom u povoljniju budućnost. Na čelna mjesta Saveza komunista Hrvatske (SKH) 1967. došli su mladi ljudi predvođeni Mikom Tripalom i Savkom Dabčević-Kučar koji su unosili ideje modernizacije, posebno u uvažavanju nacionalnog cimbenika, u prihvaćanju tržišnoga mehanizma prilagođenog socijalističkog privredi i većoj vjeri u ideologiju samoupravljanja. Međutim, iste te godine pojavila se "Deklaracije o nazivu i položaju hrvatskog književnog jezika" koju su potpisali predstavnici 18 znanstvenih i kulturnih institucija na čelu s Maticom hrvatskom s ciljem da se prigodom ustavnih promjena izmijeni odredba o jeziku. U Deklaraciji se tražilo da se ukine dvoimeni naziv jezika i uvede ime hrvatski, a ne hrvatsko-srpski jezik, tako da bi po ustavu bila ravnopravna četiri jezika: slovenski, hrvatski, srpski i makedonski. Deklaracija je izazvala revolt kao da se radilo o pobuni protiv države. Kampanju je pokrenuo potpredsjednik Sabora i član Centralnog komiteta SKH Miloš Žanko, međutim ona se brzo ugasila. Deseta sjednica Centralnog komiteta SKH koja je održana od 15. - 17. siječnja 1970. nastavila je trend demokratizacije i liberalizacije, te je osuđeno unitarističko jugoslavenstvo i savezni centralizam što je dalo snažan novi zamah dotadašnjim tendencijama jačanja hrvatske državnosti i nacionalnog identiteta uz blagoslov jugoslavenskog predsjednika Josipa Broza Tita. Više od godinu dana kasnije, točnije 30. lipnja 1971. Savezna skupština usvojila je amandmane na Ustav SFRJ koji su trebali osigurati pravo republikama da raspolažu svojim dohotkom, kao i pravičnu raspodjelu deviznog prihoda od turizma i deviznih doznaka, što je bilo od vitalne važnosti za Hrvatsku koja je ostvarivala najveći prihod od turizma i primala najveće doznake, jer hrvatskih je radnika bilo najviše na radu u inozemstvu (Bilandžić, 1999: 489-595).

Studentska gibanja 1968. pogotovo u Zagrebu rezultirala su dolaskom na scenu nove generacije studenata i studentskih vođa nazvanih "generacija lipnja" koji nisu samo namjeravali biti studentski rukovodioci nego su se pokušali izboriti za širu i veću poziciju u društvu (Ponoš, 2007: 43). U nju su spadali između ostalih Damir Grubiša kao službeni kandidat Saveza studenata Zagreba (SSZ) za studenta-prorektora, Slobodan Lang kao predsjednik Saveza studenata $\mathrm{Hr}$ vatske (SSH), Dag Strpić kao glavni urednik Studentskog lista, Dragutin Lalović i Marko Melčić kao autori u Studentskom listu, Žarko Puhovski i Antun Vujić iz Omladinskog tjednika i drugi (ibid.: 40, 75, 112-113). Paradžik koji 
nije spadao u tu generaciju, u studentski je politički život ušao također 1968. kada je na Pravnom fakultetu Sveučilišta u Zagrebu biran u Fakultetski odbor Saveza studenata, a u Studentskom je domu "Nina Maraković" u Šarengradskoj ulici bio predsjednik Savjeta stanara, dok je izabran i dva puta za predsjednika Zavičajnog kluba studenata Hercegovine. "Generacija lipnja" dominirala je hrvatskom studentskom scenom sve do izbora Ivana Zvonimira Čička za studenta-prorektora Zagrebačkog sveučilišta 21. prosinca 1970., izbora Dražena Budiše za predsjednika Skupštine SSZ 4. travnja 1971. i izbora Ante Paradžika za predsjednika SSH 18. svibnja 1971. u Dubrovniku. SSH se profilirao u samostalnu društveno-političku organizaciju, a republičko obilježje dobiva nakon osnutka sveučilišta u drugim hrvatskim gradovima potkraj šezdesetih. Kao takvo, prema saveznim i republičkim protokolima imali su i pravo nazočiti svim političkim tribinama. Upravo će isprva mnogi pripadnici "generacije lipnja" biti glavni suparnici navedenim novoizabranim studentskim vođama krajem 1970. i početkom 1971. godine (ibid.: 43). Na osnivačkoj skupštini SSH-a u Dubrovniku kao službeni predstavnici SKH bili su Ema Derossi Bjelajac, Pero Kriste, Nikola Ban i Zdravko Tomac. Kako navodi Tomac, oni su na skupštini bili srdačno pozdravljeni i u kasnijim djelima bilježi: "Govorio sam o Amandmanima na Ustav iz 1971. i bio prekidan burnim pljeskom kad god sam spomenuo neke riječi kao što su hrvatska država, nacionalna ravnopravnost i druge, bez obzira na sadržaj moga govora" (Tomac, 2012: 90-91). Netom prije izbora za predsjednika SSH, Paradžik je primljen u Savez komunista. Prema Derossi Bjelajac, partijski vrh je vjerovao da će sa Paradži- kom i ostalim članovima studentskog vodstva dobro surađivati (ibid.). U to vrijeme studentske vođe Paradžik, Budiša i Čičak često su sudjelovali na osnivačkim skupštinama Matice Hrvatske a poznati "matičari” Vlado Gotovac, Marko Veselica, Hrvoje Šošić, Šime Đodan često su gostovali na studentskim tribinama. Tako su 2. lipnja 1971. Paradžik, Budiša i Čičak nazočili osnivanju Ogranka Matice hrvatske u Trogiru, gdje je Paradžik u svom govoru simbolički identificirao hrvatski narod sa Maticom hrvatskom, naglasivši da svaki napad na Maticu hrvatsku istodobno predstavlja i napad na Hrvatsku, jer ona je svijest hrvatskog naroda, pa onaj, koji joj oduzima slobodu akcije, "oduzima i slobodu hrvatskom narodu, a to hrvatski sveučilištarci ubuduće neće dozvoliti", te "da ćemo biti sretni ako se Matica Hrvatska proširi na sve krajeve gdje žive Hrvati” (Izvještaj... 2002: 130, 409). Ubrzo nakon toga Paradžik i Budiša su 5. i 6. lipnja 1971. predvodili hrvatsku delegaciju na 9. izbornoj konferenciji Saveza studenata Jugoslavije (SSJ) na kojoj je trebalo prihvatiti novi statut SSJ i programska načela. Već je rasprava o 1. članku novog statuta pokazala nepremostive razlike između hrvatske i drugih delegacija. Hrvatska je delegacija tražila promjenu naziva organizacije do koje nije došlo što je rezultiralo napuštanjem konferencije hrvatske delegacije. Sjednica tako nikad nije završena, a SSJ je ušao u povijest Jugoslavije kao prva savezna organizacija koja se raspala. Paradžik je kao predsjednik SSH-a sredinom srpnja 1971. pokazao velike političke ambicije kada je prosvjedovao Radnom predsjedništvu 4. sjednice konferencije SKH na koju su pozvani predstavnici svih društveno-političkih organizacija osim predstavnika SSH. On je sa Budišom došao na spome- 
nutu Konferenciju SKH, međutim, njima dvojici nije bilo dopušteno da sudjeluju u njezinom radu, što je rezultiralo priopćenjem SSH-a od 14. srpnja 1971. koje je pak rezultiralo donošenjem zaključaka među kojima su bili i oni zahtjevi "da predstavnici studenata ubuduće budu pozvani na sve političke skupove svih nivoa SR Hrvatske" te traženje "najhitnijeg formiranja studentskih vojnih teritorijalnih jedinica i osnivanje zajedničkog štaba općenarodne obrane pri SSH" (Ponoš, 2007: 137). Taj zahtjev imao je svoje uporište i u kontekstu tada nastajuće Teritorijalne obrane.

Ključno pitanje ujesen 1971. bila je rasprava o amandmanima na Ustav Socijalističke Republike (SR) Hrvatske kojim se trebalo odlučiti kako će Hrvatska biti definirana (kao nacionalna država ili na neki drugi način, pitanje samoodređenja naroda, određivanje imena službenog jezika, glavnog grada republike, himne itd.). Zbor studenata općenito je izrazio nepovjerenje Ustavnoj komisiji, a 15. listopada 1971. u Rijeci na sastanku predstavnika svih samoupravnih organa i društveno-političkih organa Sveučilišta koji je bio posvećen ustavnim promjenama u SR Hrvatskoj, Paradžik je podržao studentsku ideju o produžetku roka za raspravu te je konstatirao da u raspravi uglavnom ne sudjeluju radnici i seljaci, da službeni jezik treba biti hrvatski, a pismo latinica. Svi (tu je mislio na Srbe, Talijane, Čehe) imaju pravo razvijati svoje nacionalne osobitosti, a u narodnoj obrani trebalo je prema njemu osigurati da hrvatski kadar bude zastupljen razmjerno ostalima, dok vrhovni organ narodne obrane treba biti Savjet narodne obrane Hrvatske (ibid.: 169).

Političko stanje sredinom listopada 1971. u SR Hrvatskoj doslovno je vrilo. Nacionalni zanos među studentima nije prestajao nego je sve više jačao i uz Maticu hrvatsku i reformsko krilo SKH tražena je afirmacija nacionalnog identiteta i hrvatskog suvereniteta na političkom, gospodarskom i kulturnom planu. Studenti su na određeni način podupirali zaključke Desete sjednice Centralnog komiteta SKH. Hrvatski partijski vrh se već izborom novih studentskih lidera raskolio na dvije frakcije: reformska, predvođena Tripalom, Dabčević-Kučar i Perom Pirkerom koja je poslije nazvana "proljećarskom" ili "maspokovskom" i "unitaristička" koju je predvodio vodeći hrvatski komunist Vladimir Bakarić, a jedan od prvih uspjeha "unitarista" bilo je isključenje Marka Veselice i Šime Đodana iz SKH zbog nacionalizma i frakcionaštva. Kulminacija napetosti je bila isključenje Jure Šarića iz Republičkog vijeća Saveza sindikata Hrvatske što je rezultiralo štrajkom hrvatskih sveučilištaraca koji je započeo 22. studenog 1971. godine. Štrajk je proglasio Goran Dodig, potpredsjednik SSZ, te je bilo predviđeno da će trajati od 23. studenog do 3. prosinca 1971. godine. Razlog štrajka su bile hrvatske devize koje su završavale izvan granice SR Hrvatske u državnom središtu. Četiri osnovna cilja štrajkaša iznesena su na zboru hrvatskih sveučilištaraca: 1. Pružiti podršku zahtjevu za konstituiranjem Hrvatske kao suverene države hrvatskoga naroda; 2 . Pružiti podršku rukovodstvu SKH; 3. Potaknuti uklanjanje protivnika reformskih kretanja i obraniti se od njihovih napada i 4 . Potaknuti bržu promjenu deviznog sustava u korist Hrvatske (Knezović, 1995: 231).

Zahtjev za većom samostalnošću Hrvatske osobito je bio izražen u istupima Paradžika. Tako je on u uvodnom izlaganju na zboru hrvatskih sveučilištaraca 22. studenog 1971. sumirajući zahtjeve studenata, posebno isticao njiho- 
vu zainteresiranost za jasno definiranje hrvatske državnosti i pune ravnopravnosti svih građana koji žive u SR Hrvatskoj i smatraju je svojom domovinom. Paradžik je zamjerao amandmanima na ustav SR Hrvatske nepreciznost koja otvara prostor za dvojaka tumačenja. Pri tome je nudio studentsku preformulaciju amandmana. U njima je istaknuto kako je hrvatski narod kroz narodnooslobodilačku borbu i revoluciju ostvario svoju nacionalnu državu SR Hrvatsku i polazeći od prava na samoopredjeljenje i odcjepljenje on se sa ostalim narodima udružio u zajednicu ravnopravnih naroda SFRJ. Studentski amandmani definiraju SR Hrvatsku kao suverenu i nacionalnu državu hrvatskoga naroda koja osigurava ravnopravnost svim svojim građanima bez obzira na nacionalnu, vjersku, rasnu i drugu pripadnost, gdje je službeni jezik hrvatski, pismo latinica, Zagreb glavni grad a himna "Lijepa naša domovino". Narodnostima se jamči pravo na slobodno i ravnopravno upotrebljavanje i izražavanje svih oblika nacionalnih osobitosti. Postupak pred sudovima i drugim organima vodi se na hrvatskom jeziku. Hrvatski jezik mora biti službeni i u saveznoj vojsci, a hrvatski građani moraju služiti vojsku na svom teritoriju. Admiralitet treba imati sjedište u Splitu. Republike se trebaju brinuti o srazmjernoj zastupljenosti naroda i narodnosti u starješinskom kadru oružanih snaga SFRJ (Hrvatsko sveučilište, 27. 11. 1971). Paradžik je isticao potrebu za oštrijom akcijom i na drugim područjima kako bi se riješilo pitanje deviznog i bankarskog sustava. Traži tako razbijanje centralističkog privrednog sustava, kao i sudjelovanje radnika na radu u inozemstvu pri formiranju ustava. Za seljake zahtijeva veći zemljišni maksimum, komasaciju i povoljno kreditiranje (Vjesnik, 25. 11. 1971). Svi studenti štrajkaši zapravo su imali jedan cilj a to je ostvarenje suverenosti Hrvatske, pri čemu su podržavali one snage za koje su smatrali da one to mogu ili bi trebale podržati, prije svega rukovodstvo SKH i Tito. Međutim, iako je rukovodstvo SKH podržavalo studentske zahtjeve, ono se protivilo štrajku kao metodi političke borbe i tražilo je prekid štrajka, jer su bili svjesni da štrajk može provocirati udar vrha vlasti Jugoslavije na Hrvatsku. Studentsko je vodstvo unatoč pritisku partijskoga vodstva uspjelo održati štrajk do predviđenog datuma, na kojeg su pozivali i radnike koji se nisu odazvali na priključenje štrajku. Za vrijeme štrajka, u Karađorđevu je 30. studenoga 1971. započeo sastanak Tita sa proširenim Izvršnim komitetom Centralnog komiteta SKH. Na udaru su bili studenti za koje je Tito tražio da budu uhićeni što je hrvatsko partijsko vodstvo i dalje odbijalo. Pri tome su posebno optuženi Matica hrvatska (koja također nije podržala štrajk) i pojava frakcionaštva u SKH pri čemu je za frakcionaštvo optužena grupa oko Tripala i Dabčević-Kučar. Presudu je donijela struja predvođena Titom i Bakarićem. Iako su "proljećari" bili u većini, matematika tu nije odlučivala. Tripalo i Dabčević-Kučar pali su 1. prosinca 1971., a odmah nakon njih i ostali partijski funkcioneri koji su bili na strani masovnog pokreta. Ante Paradžik je 3. prosinca 1971. na završnom zboru objavio prekid štrajka. U govoru je revidirao neke političke teze rekavši da ni “...vulgarni nacionalizam kao ni dogmatizam (...) nikad nije imao uspjeha na Sveučilištu (...) Humanizam i demokratski socijalizam su odrednice i ovoga studentskog pokreta" (Dabčević-Kučar, 1997: 779). Govoreći pozitivno o SFRJ koja ne znači negaciju individualnosti nacija citira Titove riječi iz 1963. “...a svako zapovijedanje, težnja za hege- 
monijom i nametanje bilo bi samoubojstvo" (ibid.). U završnom dijelu govora pozvao je studente da "...čvrsto stoje na progresivnoj platformi 22. sjednice CK SKH-a" završivši govor time da je studentski radikalizam uvjetovan "borbom za socijalističku budućnost svih nas i čitave jugoslavenske zajednice..." (ibid.). Prema kasnijem svjedočenju Paradžika, upravo je Bakarić bio idejni začetnik štrajka. "Izmislio je taj štrajk da bi došlo do nemira i svega onoga što se dogodilo u Hrvatskoj, da bi srušio demokratsku struju na čelu sa Savkom, Tripalom i drugima" (Pavković, 1991: 63).

Nakon odluka iz Karađorđeva i završetka štrajka, uslijedila su uhićenja studentskih vođa Ivana Zvonimira Čička, Dražena Budiše i Gorana Dodiga dok je Paradžik prema napisima u medijima bio u bijegu (Vjesnik, 13. 12. 1971.). Zatim su uslijedila i suđenja. Sam Paradžik je izjavio vezano uz svoje uhićenje da on nije bio uhićen nego da se "sam prijavio 13. prosinca 1971. godine". Nadalje je kazao: "Naime, čuo sam preko radija, da su moje kolege uhićene dan-dva ranije, pa sam iz doma na Trgu žrtava fašizma pobjegao i sakrivao se dva dana. U novinama i ostalim medijima bilo je objavljeno da sam u bjekstvu. Međutim, sakrio sam se u jednom stanu u Zagrebu i gledao što se tih dana događalo na glavnim ulicama ovoga grada. Neki su željeli da bježim, da se na taj način spasim, ali sam to kategorički odbio, tim više što sam bio predsjednik SSH. Bio bi to po meni znak krivnje i kukavičluka. Nisam želio nikuda odlaziti iz Hrvatske. Odlučio sam se prijaviti i na taj način dokazati svoju istinitost i pravdu. Prijavio sam se javnom tužitelju Slobodanu Budaku, a on me izručio predsjedniku Okružnog suda" (Pavković, 1991: 61). Optuženom studentskom vodstvu sudilo je peteročlano Veliko vijeće Okružnog suda u
Zagrebu kojemu je predsjedavao sudac Milenko Mihaljević. Suđenje je počelo 5. srpnja, a nastavljeno je u kolovozu i rujnu 1972. godine. Prvooptuženi je bio Budiša, drugooptuženi Čičak, trećeoptuženi Paradžik kojeg je branio Slavko Šimatović, a četvrtooptuženik Dodig branio se sa slobode. Optuženi su po članku 100. Kaznenog zakona kao kontrarevolucionari koji napadaju državu, narod i društveno uređenje. Optuženi su i da su stvorili "militantnu, u suštini terorističku i nacionalističkim fanatizmom i šovinizmom zadojenu falangu, pokret hrvatskih sveučilištaraca, pod izravnim idejnim i organizacijskim rukovodstvom kontrarevolucionarne grupe koja je djelovala u središtu Matice hrvatske". Paradžik se na suđenju branio šutnjom a u završnoj riječi rekao je da "optužnicu smatra montiranom" i da je "zbog toga odbacuje". Suđenje je nazvao "procesom" koji ga "pogađa i ponizuje" (Perić, 2007: 346). Početkom listopada 1972. izrečene su presude. Sva četvorica proglašena su krivima a Paradžik je osuđen na tri godine zatvora i dvije godine zabrane javnog djelovanja. Zatvorsku je kaznu u cijelosti odslužio u Lepoglavi.

Sudbinu Paradžika nakon izlaska iz zatvora opisao je Dražen Budiša sredinom devedesetih: "Kada je Ante Paradžik izišao nakon tri godine iz zatvora i došao u Ljubuški, cijela njegova generacija koja je sudjelovala u tom pokretu (Hrvatsko proljeće op. a.) već je ondje namještena na položajima direktora škola, veterinara, sudaca. Dolazi Ante Paradžik i on je opasnost. Oni su se afirmirali, nisu ušli u dosje Udbe, i sada dolazi on, a oni su nekad bili zajedno, znaju što tko misli i bježe od njega. Da bi ipak sačuvali svoj hrvatski obraz, lansiraju da je on počeo surađivati sa Udbom u Zagrebu, i nitko od njih sa njim ne kontaktira, a čovjek nakon tri godine dolazi u svoje 
mjesto. Onda je on još četiri puta hapšen" (Dabčević-Kučar, Gotovac i Budiša, 1996: 18).

Nakon izlaska iz zatvora 1975., Paradžik se vratio studiju prava, kojeg je ponovno prekinuo jer je iste godine ujesen uhićen zajedno sa svojom zaručnicom Jozefinom Oberan. Oberan je idućeg dana bila puštena, međutim Paradžik je osumnjičen za najteža djela, između ostalih za "kupovinu tenkova u Austriji” (Jutarnji list, 14., 15. i 16. 4. 2001). U zatvoru provodi četiri mjeseca, bez suđenja, bez prava na posjet, a onda ga sud pušta na slobodu. Nadalje, od iste je godine Paradžika zbog hrvatskog nacionalizma pratila i obrađivala jugoslavenska obavještajna Služba državne sigurnosti. Od tri postojeće kategorije obrada Paradžik je bio u onoj najtežoj operativnoj obradi koja je značila sustavnije praćenje osoba (Gaura Hodak, 2015). Godinu dana kasnije, 6. prosinca 1976. po treći je put uhićen i osuđen na 60 dana zatvora zbog toga što je na svojim pozivnicama za vjenčanje sa Jozefinom Oberan imao hrvatsku trobojnicu bez socijalističkih oznaka (Pavković, 1991: 68-70). Time je Paradžik "na javnom mjestu pisanjem vrijeđao i omalovažavao patriotska osjećanja građana i društveno političko uređenje Jugoslavije." Vjenčani kum bio mu je Budiša. Četvrti je put uhićen 1977. u Zagrebu a da ni sam nije znao zašto (vjerojatno zbog dolaska Tita u Zagreb op. a.) (Paraga i Paradžik, 1991: 239). Usprkos teškom teretu pritiska vlasti, Paradžik je 1978. diplomirao pravo na Pravnom fakultetu Sveučilišta u Zagrebu, gdje je apsolvirao na trećem stupnju iz područja obiteljskog prava. Uspio se zaposliti

1 Osobna pismohrana (OP) obitelji Ante Paradžika: Rješenje Opštinskog suda za prekršaje Ljubuški br. 716/76 od 8. prosinca 1976.
1979. u Centru sa socijalni rad u Donjoj Stubici. Tamo je pomagao socijalno ugroženim osobama u kojoj mu je bio dodijeljen i stan. Problemi su ubrzo nastali kada su lokalne vlasti u Donjoj Stubici saznale za Paradžikovu aktivnost iz 1971. pa je ubrzo dobio otkaz, nakon čega se žalio Vrhovnom sudu koji ga je ponovno vratio na posao (Pavković, 1991: 71)

\section{Djelovanje uoči i tijekom uspostave višestranačja}

Paradžik nije u javnosti nastupao sve do 10. prosinca 1988. kada je na Dan ljudskih prava sa grupom od oko 40 bivših političkih zatvorenika, među kojima su bili Dražen Budiša, Marko Veselica, Hrvoje Šošić i Vladimir Šeks želio unaprijed najavljeno predati u Saboru SR Hrvatske Prosvjed - dokument koji je sastavljen radi ograničavanja temeljnih ljudskih prava u Hrvatskoj, osobito onih koja se odnose na slobodu kretanja i oduzimanje putovnice s obrazloženjem da to zahtijevaju interesi javnog poretka i/ili obrana zemlje. Prosvjed je trebao biti predan predsjedniku Sabora SR Hrvatske Anđelku Runjiću i predsjedniku Predsjedništva SR Hrvatske Ivi Latinu koji ih nisu primili, niti su tada bili nazočni u zgradi Sabora. Prosvjednici su tada zamolili osoblje na porti Sabora da ih predsjednici prime u vrijeme kada oni odrede, međutim nisu bili nikada pozvani na susret (Šošić, 1993: 695-697). U neku ruku to je bio jedan od prvih političkih činova koji su nagovještavali društveno-političke promjene u SR Hrvatskoj. Paradžik je ubrzo sudjelovao i u osnivanju Hrvatskog društva političkih zatvorenika u kojem je bio glavni tajnik, a ta je udruga počela djelovati 1989. godine. Njezina osnivačka skupština održana je 17. veljače 1990. godine (ibid.: 262). 
Paradžik je u to vrijeme dobio putovni$\mathrm{cu}$, nakon 19 godina $\mathrm{i}$ to na intervenciju ministra vanjskih poslova Austrije Aloisa Mocka, zbog simpozija "Hrvatska i Europa” koji se održavao u Grazu (Pavković, 1991: 71).

Proces demokratizacije i uspostava višestranačja u SR Hrvatskoj, koji se mogu pratiti od 1989. pokazali su jednu zanimljivu činjenicu. Ona se očituje u tome da je svaki od studentskih vođa iz Hrvatskog proljeća krenuo svojim političkim putem. Tako se Budiša pridružio Hrvatskom socijalno-liberalnom savezu (HSLS) prvoj opozicijskoj stranci u Hrvatskoj osnovanoj nakon Drugog svjetskog rata, dok je Ivan Zvonimir Čičak bio među dužnosnicima obnovljene Hrvatske seljačke stranke (HSS) u domovini (Dunatov, 2010: 384-385, Matković, 1999). Paradžik je 1989. pristupio Inicijativnom krugu Hrvatske demokratske zajednice (HDZ), gdje je bio u krugu ljudi koji su podržavali Marka Veselicu za predsjednika. Pored toga, bio je među autorima koji su pisali statut HDZ-a. U konačnici, Paradžik je bio jedan od članova Inicijativnog kruga HDZ-a koji je tražio od Tuđmana izbacivanje ZAVNOH-a i AVNOJ-a kao temelja hrvatske državnosti iz Prednacrta HDZ-a što je Tuđman odmah odbio (Knežević, 2015: 35). Komentirajući razloge razilaženja sa HDZ-om Paradžik je navodio kako je u toj stranci bilo dosta onih koji su prije bili protiv samostalne Hrvatske i koji su ga progonili za vrijeme komunizma. " $U$ HDZ su mnogi ušli radi karijerizma, položaja, radi lakšeg života i probitaka. Neki su još jučer bacili crvenu knjižicu, a već danas postale vatrene pristalice HDZ-a. Da je bar zadržana jedna selekcija, kao npr. da nitko ne može biti član jedne takve stranke koji nije "na vrijeme" vratio crvenu knjižicu ili da mogu biti svi oni koji zadnjih pet godina nisu bili u Partiji. To bih pozdravio" (Pavković, 1991: 72). S druge strane, Hrvoje Hitrec na sljedeći je način opisao nezadovoljnu frakciju Inicijativnog kruga HDZ-a među kojima je bio i Paradžik: "Gabelica, Paradžik, Veselica, svi Hrvati od glave do pete, ali su vozili u petoj kad je trebalo u trećoj" (Hitrec, 1992: 23). Nakon što je Tuđman postao predsjednikom HDZ-a, Paradžik je bio među osnivačima Hrvatske demokratske stranke (HDS) iz koje je također istupio nezadovoljan političkim programom koji nije imao zapisan cilj o nezavisnoj hrvatskoj državi kao ni program HDZ-a. Može se stoga smatrati da je Paradžikovo istupanje iz HDZ-a i HDS-a bilo radi ideoloških pitanja.

$\mathrm{U}$ to vrijeme $\mathrm{u}$ javnosti se javio Dobroslav Paraga koji je iz Beča poslao Obavijest o inicijativi za utemeljenje pripremnog odbora za moguću obnovu Hrvatske stranke prava, sa sjedištem u Zagrebu. Hrvatska i šira jugoslavenska javnost za Paragu je saznala 1980. kada je kao zagrebački student prava i teologije organizirao sastavljanje peticije upućene Predsjedništvu SFRJ za amnestiju političkih zatvorenika nakon čega je bio uhićen i osuđen na četiri godine zatvora koje je odslužio na Golom otoku i u Lepoglavi. Amnesty International proglasio ga je dva puta zatvorenikom savjesti (Veselinović, 2014: 57) a hrvatska historiografija navodi kako je riječ o najmlađem jugoslavenskom disidentu (Spehnjak i Cipek, 2007: 281). Izlaskom iz zatvora, Paraga se kao istaknuti borac za ljudska prava u američkom Kongresu 1989. izborio za izglasavanje Rezolucije 169 koja osuđuje SFRJ zbog kršenja ljudskih prava i zatvaranja političkih protivnika. Pored SAD-a Paraga je o montiranim sudskim procesima političkim protivnicima i kršenju ljudskih prava govorio i u Njemačkoj, Austriji i bivšoj Čehoslovačkoj 
gdje su ga primali vodeći državni dužnosnici (Paraga, 1995). U navedenoj Obavijesti glavni povijesni i politički cilj HSP-a bio bi uspostava slobodne i samostalne hrvatske države na etničkom i povijesnom području hrvatskog naroda i naroda koji s njim u zajednici živi, te pridobivanje potpore odlučujućih svjetskih čimbenika za taj program. U Obavijesti je bilo govora o prvim višestranačkim izborima 1990. u Hrvatskoj za koje je Paraga smatrao "da će se održati bez elementarnih demokratskih pretpostavki za slobodno stranačko djelovanje nezavisnih hrvatskih političkih stranaka, pokreta, društava i pojedinaca iz Hrvatske i inozemstva" (Paraga i Paradžik, 1991: 233-235).

Nakon pročitane Paragine Obavijeti Paradžik je osnovao u Zagrebu Inicijativni odbor za obnavljanje HSP-a. Odbor za obnavljanje HSP-a kojeg su činili Paraga, koji je tada boravio u SAD-u, Paradžik i Krešimir Pavelić koji je istupio iz HDS-a sastao se 25. veljače 1990. na Obnoviteljskom saboru HSP-a koji je prihvatio privremena Temeljna načela i Statut HSP-a, a 27. veljače HSP biva registrirana kao devetnaesta po redu politička stranka u Hrvatskoj koja je počela djelovati na političkoj pozornici. Inicijativni odbor postao je Obnoviteljski sabor HSP-a koji je izabrao odgovarajuća tijela Stranke. Za predsjednika je predložen i izabran Paraga, za dopredsjednika Paradžik ${ }^{2}$, a za tajnika Pavelić. Njih trojica činili su Predsjedništvo koje će obavljati svoju dužnost kao privremeno vodstvo dok ne bude na Prvom općem Saboru izabrano novo ili potvrđeno posto-

2 Zbog Paraginog službenog boravka u SAD-u, Paradžik je u početku bio i obnašatelj dužnosti predsjednika HSP-a. (op. a.) Tek se u kolovozu 1990. Paraga definitivno vratio iz SAD i preuzeo predsjedanje HSP-om (Blažeković, 2007). jeće vodstvo nadopunjeno s novim dužnosnicima (ibid.: 236). Obnavljanjem HSP-a 25. veljače 1990. donesena su i Programska načela stranke kojom pristaše ideje hrvatskog državnog prava prihvaćaju tu ideju kao polaznu osnovu svoje djelatnosti. Programska načela trebala su biti privremena sve do prvog redovitog Sabora, kada je predviđeno usvajanje programa HSP-a u skladu sa suvremenim kretanjima u domovini, Europi i svijetu. Polazeći od povijesnog hrvatskog državnog prava i prava naroda na samoodređenje uključujući pravo na odcjepljenje, HSP će se "zalagati za hrvatski nacionalno-državni suverenitet na cjelokupnom povijesnom i etničkom prostoru, bez kojeg nema ostvarenja višestoljetnih težnji hrvatskog naroda".

Uspostavom višestranačja u Hrvatskoj nacionalno pitanje u svim svojim aspektima iz prošlosti bilo je istaknuto u programima većine političkih stranaka. Pogotovo su se otvorila ona pitanja koja su bila nakon 1945. tabuizirana. Delegacija HSP-a predvođena Paradžikom sudjelovala je 1990. u komemoracijama hrvatskim žrtvama na Bleiburškom polju i javno je pozivala predstavnike hrvatskih političkih stranaka da se pridruže tom činu, kada se ujedno obilježavala 45. obljetnica od bleiburške tragedije. Tada su hrvatski su mediji prvi put izvijestili o komemoraciji na bleiburškom polju, na kojoj su pored pravaša bili i predstavnici drugih stranaka: Tomislav Duka (HDZ), Marko Veselica (HDS), Dražen Budiša (HSLS) te Srećko Pšeničnik iz Hrvatskog oslobodilačkog pokreta (Veselinović, 2014: 62). Nadalje, na komemoraciji nad jamom Jazovka, Paradžik je između ostalog rekao: "HSP s

3 OP obitelji Ante Paradžika: Programska načela Hrvatske stranke prava, Zagreb, 25. veljače 1990., 1. 
ovoga mjesta upućuje sućut cijelom hrvatskom narodu. Tu su sućut trebali uputiti crveni zlotvori - hrvatski izdajnici koji su izvršili pokolj nakon Drugog svjetskog rata nad hrvatskim narodom. Ovdje je prva od otkrivenih jama u poratnoj tragediji hrvatskog naroda. $\mathrm{Ni}$ nove Hrvatske ne bi bilo da nije bilo ovih žrtava. Nova Hrvatska se danas rađa iz naših tragedija na Bleiburgu, na Križnom putu i u svim onim jamama u koje su bačeni oni kojima je krivnja bila $\mathrm{u}$ tom što su se borili za svoju samostalnu Hrvatsku državu... A mi želimo živjeti na svom prostoru u miru i u svojoj slobodnoj državi. Želimo živjeti u ljubavi sa svim drugim narodima i državama” (Paraga i Paradžik, 1991: 77-78).

Paradžik je odmah nakon obnavljanja HSP-a postao jedan od najaktivnijih stranačkih dužnosnika. U javnosti je zahtijevao potrebu ostvarenja hrvatske samostalnosti. Tako u intervjuu za časopis Azur iznosi stavove da se "zalaže da se ne odstupi od povijesnog hrvatskog državnog prava i prava na samoodređenje, uključujući i pravo na odcjepljenje" i "da na Jugoslaviju gleda kao prošlost, jer se HSP opire ideji jugoslavenskog integralizma kao ideji koja je povijesno nadiđena, nazadna i za sve narode sadašnje države u najvećoj mjeri štetna" (ibid.: 2224). Komentirajući stanje na Kosovu smatrao je da Albanci imaju ista prava kao i Srbi, te je isticao da je protivnik "iseljavanja bilo kojeg naroda s njegovog životnog prostora” (ibid.: 25). Nadalje, isticao je da se zalaže za denacionalizaciju nepravedno oduzete imovine i privatno vlasništvo jer se ono univerzalno pokazalo kao osnovni pokretač efikasne privrede u uvjetima tržišne ekonomije (ibid.: 22, 27). Smatrao je i da se nezaposlenost može riješiti izgradnjom novih autocesta i to one Zagreb-Split i OsijekSarajevo-Ploče (ibid.: 27-28). Zalagao se za alternativne oblike iskorištavanja energije, smatrajući da je NE Krško potencijalna opasnost (ibid.: 27). U konačnici po pitanju obrazovne politike tražio je slobodu odgojno-obrazovnih ustanova od svake ideološke isključivosti, njihovo uključivanje i suradnju na međunarodnoj razini, te je smatrao da školovanje mora biti besplatno na svim razinama, a standard učenika i studenata viši (ibid.: 29).

Uoči prvih višestranačkih izbora u Hrvatskoj koji su se održali u travnju i svibnju 1990. Predsjedništvo HSP-a donijelo je odluku da neće sudjelovati na izborima zbog toga "jer će se izbori obavljati pod nadzorom političke policije koja je pod nadzorom komunističkih vlasti i zbog toga jer jugoslavenska diplomatska predstavništva $\mathrm{u}$ inozemstvu odbijaju dati vize emigrantima iako su hrvatski državljani i tako im onemogućuju izlazak na izbore" (ibid.: 21). Međutim, iako nisu sudjelovali na izborima Paradžik i Pavelić uvode HSP u Hrvatski demokratski blok (HDB) kojeg su činili HDZ, jedna frakcija HSS-a, Hrvatska stranka, Demokratsko kršćanska stranka i Demokratska akcija Hrvatske. HDB je bio nacionalni blok koji počiva na sintezi hrvatske državotvorne misli i nema zajedničke ideologijske osnove, već mu je poveznica zagovaranje hrvatskog interesa bez jugoslavenskog okvira. Stranke okupljene u tom bloku išle su samostalno na izbore, a dogovorile su se da u drugom izbornom krugu podrže kandidate iz bloka koji dobiju najviše glasova (Šošić, 1993: 242). Između Paradžika i Tuđmana koji je bio vodeća osoba u bloku postignut je usmeni dogovor da će nakon izbora i eventualne pobjede HDB-a Paradžiku biti ponuđeno mjesto potpredsjednika u novom sazivu Vlade ili Predsjedništva SR Hrvatske. Odluku o ulasku u blok predvođen HDZ-om do- 
nijelo je vodstvo stranke usprkos protivljenju Parage koji je tada boravio u SAD-u (Bilandžić, 2001: 561). Dopredsjednik HSP-a Paradžik pozvao je svoje članstvo da glasuje za taj blok jer je to bio prema njegovoj prosudbi od svih loših programa najmanje loš i “jer smo pod svaku cijenu željeli da komunisti izgube izbore, a njih su mogli pobijediti jedino ljudi iz HDZ-a predvođeni dr. Tuđmanom" (Paraga i Paradžik, 1991: 36). Nakon održanih izbora Tuđman kao pobjednik izbora mijenja odluku i umjesto Paradžika u saziv Predsjedništva SR Hrvatske na mjesto potpredsjednika poziva Dušana Bilandžića iz SKH-SDP nakon čega HSP izlazi iz bloka što je rezultiralo Paradžikovim kritikama na račun politike HDZ-a i Tuđmana. Paradžik je smatrao da HDZ, kao i druge demokratske stranke nisu trebale primati u svoje redove komuniste koji nisu barem prije pet godina izišli iz Partije jer su, prema njemu, mnogi komunisti samo iz taktičkih razloga nakon izbora promijenili stranačke knjižice, a u osnovni su zadržali stari politički mentalitet. Pogotovo je kritizirao obećanje koje je Tuđman davao na svojim predizbornim skupovima da će svi oni kadrovi koje je komunistička vlast postavila na temelju njene procjene o podobnosti biti smijenjeni jer su $\mathrm{u}$ stvari "sve strukture koje je postavila bivša komunistička vlast, boljševička, ostale su na vlasti, ostale su u strukturama privrede, od kadrovika, direktora, savjetnika, i oni danas pljačkaju i uništavaju hrvatsku privredu. Uništavaju je jer je nisu ni dosad štedjeli. Te ljude je trebalo odmah suspendirati” (ibid.: 138). Kritika nove vlasti nastavila se i u sljedećem razdoblju. Ustav koji je Sabor proglasio 22. prosinca 1990. za HSP je bio nametnuti, oktroirani Ustav jer ga je Sabor donio bez prethodne suglasnosti hrvatskoga naroda. Ustav po kojem hrvatski narod nema svog državnog suvereniteta bio je po pravaškom vodstvu "antihrvatski i antinarodni" (ibid.: 166). Nadalje, oni su tvrdili da po tako nametnutom Ustavu hrvatska država nema svoje vojske, redarstva, novca, diplomatskih predstavništva i nije mogla biti međunarodno priznata. Po tom Ustavu Hrvatska se ne pojavljuje kao subjekt međunarodnog prava i zato se Hrvatska nije mogla naći na međunarodnoj političkoj karti. Na to se nadovezala kritička primjedba da je Hrvatska i dalje ostala u sastavu Jugoslavije. Na protujugoslavenskom gledištu HSP tražila je brisanje ZAVNOH-a iz preambule Ustava “jer je odluke ZAVNOH-a i AVNOJ-a donijela Komunistička partija Hrvatske i Jugoslavije, a nikako hrvatski narod kojem su te odluke silom nametnute" (ibid.: 89). Paradžik je kritizirao i odluku da se 30. svibnja slavi kao Dan državnosti jer je smatrao kako se ne može slaviti Dan državnosti na dan 30. svibnja kada još Hrvatska pravno nije država. To je po njemu bio dan uspostave demokracije, a za nezavisnu državu Hrvatsku se trebalo tek izboriti i to je morala biti glavna zadaća HSP-a. U tom smislu on poručuje: "HDZ nakon što je proglasio 30. svibnja za Dan državnosti mogla je putem Hrvatskog sabora proglasiti i hrvatsku državnu samostalnost. No kada to već nije tada učinila, mogla je prije svih drugih na ovim prostorima organizirati plebiscit hrvatskog naroda i građana Hrvatske u domovini i dijaspori, kako bi se točno utvrdilo žele li Hrvati i građani Hrvatske samostalnu hrvatsku državu ili ne" (ibid.: 215).

Politička zbivanja u SR Hrvatskoj su nakon prvih višestranačkih izbora bila itekako burna i napeta jer dio hrvatskih građana srpske nacionalnosti nije prihvaćao nastale promjene, što je rezultiralo pobunom koju je vodila Srpska demokratska stranka protiv demokratski 
izabrane vlasti. Pobuna je bila uvod $\mathrm{u}$ agresiju širih razmjera na Hrvatsku koju je planirala i vodila Jugoslavenska narodna armija (JNA) koja je netom prije promjene vlasti oduzela oružje republičkoj Teritorijalnoj obrani i time dodatno otežala i obrambenu situaciju u Hrvatskoj (Barić, 2005). U takvoj političkoj situaciji Paradžik je tražio formiranje Vlade nacionalnog jedinstva. Smatrao je da bi se hrvatske političke stranke trebale ujediniti; "predložio bih samo dvije stranke: Hrvatsku stranku i Stranku hrvatskih izdajnika. A kada dobijemo svoju državu, svoju slobodu, onda neka bude stotinu stranaka. Neka bude tada i političkih svađa i više demokracije. A što se tiče srpskih stranaka kao jednonacionalnih stranaka, to se ne bi smjelo dopustiti. Oni se mogu angažirati u hrvatskim strankama, jer osnivanjem svojih stranaka oni odmah stvaraju politički prostor, političko djelovanje i stvaraju pretpostavku za svoju državu. Ne mogu Hrvati imati svoju političku stranku u Njemačkoj ili Austriji. Hrvata u Australiji ima oko 300 tisuća pa ne mogu zamisliti svoju stranku. Takvi su zahtjevi apsurdni” (Paraga i Paradžik, 1991: 188). Iz navedenog prijedloga o samo dvije stranke, vidljivo je da je Paradžik preuzeo učenje pravaškog ideologa i prvaka Eugena Kvaternika o jednoj stranci koja će braniti narod, a druga razarati ga (Gross, 2000: 138). Navedenu tezu Paradžik je često zastupao na stranačkim tribinama, a zadnji put je to bilo netom prije ubojstva.

Prvi opći Sabor HSP-a održan je 23. i 24. veljače 1991. u Zagrebu, u hotelu Intercontinental (danas Westin). Tom su prigodom istaknuta pravaška načela koja su trebala biti smjernice za politiku: povijesna težnja Hrvata za državnom nezavisnošću i ustrajavanje u borbi za ostvarenje povijesnih hrvatskih prava.
Na Saboru stranke izabrano je novo (staro) rukovodstvo na sljedeće četiri godine. Za predsjednika je jednoglasno izabran Dobroslav Paraga, a uz njega i tri dopredsjednika, i to Ante Paradžik, Ivica Karamatić i Vjekoslav Ćosić. Glavni tajnik je postao Krešimir Pavelić (Pavelić, 1995: 80). Na Prvom općem Saboru stranke Paraga je istaknuo kako je HSP uskrsla feniksa iz pepela, zabrana, atentata, ratova i hekatombe krvi hrvatskoga naroda, stoji ponosno sa svojom elitom u središtu svih Hrvata, u Zagrebu u kojem je u 20. stoljeću već jednom ostvaren najsvetiji ideal HSP-a i hrvatskoga naroda a to je proglašenje NDH 10. travnja 1941. godine. Nadalje je dao zavjet da će ponovno ispuniti poslanje i pravaško držanstvo i da će ponovno uskrsnuti NDH od Sutle do Drine, nadajući se već 1991. godine. ${ }^{4} \mathrm{Uz}$ pozdravljanje proglašenja NDH, Paraga je kritizirao nedemokratske i nehumane postupke vodstva represivnog ustaškog režima na čelu s poglavnikom Antom Pavelićem i odvojio je ideju o uspostavi hrvatske države od navedenih postupaka. Paraga se pozivao i na učenje Pavelića koje se odnosilo na njegov rad u HSP-u od 1919. do 1929., a ne na njega kao na vođu ustaškog pokreta za kojeg je izjavio "da ga više nema i da nije potreban jer će se HSP izboriti za nezavisnu hrvatsku državu demokratskim sredstvima te da će se prvi boriti za sprečavanje bilo kakvog nedemokratskog postupka prema drugim nacionalnim skupinama u Hrvatskoj od kojih traži odanost Hrvatskoj" (Vjesnik, 7. i 8. 10. 2003). Iako se Paraga nije pozivao na Pavelića kao vođu ustaškog pokreta i represivnog ustaškog režima mora se spomenuti da je na Prvom općem Saboru

4 Pismohrana HSP (PHSP): Prvi opći Sabor Hrvatske stranke prava, Zagreb 23. i 24. veljače 1991., VHS kazeta. 
HSP-a donijeta rezolucija koja je upućena Saboru da se iz cijelog svijeta prenesu posmrtni ostaci zaslužnih Hrvata koji su umrli prirodnom smrću ili su bili ubijeni a među njima je posebno bio Pavelić. Također je zatraženo proglašenje 10. travnja državnim blagdanom. Paragin stav bio je identičan Paradžikovom koji je rekao "da jedan narod i jedna država ne mogu biti ni fašistički ni zločinački" (...) kada smo predlagali da se 10. travnja slavi kao državni praznik nismo mislili ni na zločine, ni na režim, već na državu koju su priznale 24 zemlje svijeta de iure i 6 zemalja svijeta de facto" (Paraga i Paradžik, 1991: 185). Posljednji govornik na pravaškom Saboru bio je Paradžik. Najprije je naglasio da Hrvati hoće svoju slobodu, a ne državu, a država im je sredstvo da dođu do svoje slobode. Zatim je istaknuo kako je ovo povijesni Sabor jer s njega mora poći baklja slobode i da u svaku hrvatsku kuća treba ući državotvorna misao HSP-a koju je proklamirao jedini Otac Domovine dr. Ante Starčević. Nadalje je istaknuo kako HSP neće prihvatiti nikakve konfederacije jer je to izdaja hrvatska naroda. Također je istaknuo kako HSP nikada neće prihvatiti nikakav savez ni s kojim narodom ni s kojom državom jer Hrvatska hoće živjeti u svojoj slobodnoj i nezavisnoj državi čiji se san čeka 888 godina. Paradžik je u svom govoru tražio da se izvrši ratna reparacija za pobijene hrvatske žrtve od 1945. godine. U završnom dijelu govora istaknuo je kako se u 1991. mora stvoriti hrvatska država ili je bolje da nas nema, jer jedan dan slobode je slađi nego 50 godina ropstva. ${ }^{5}$ Stajalište HSP-a prema $\mathrm{BiH}$ polazilo je od tvrdnje da je to povijesni hrvatski teritorij i da se treba putem referenduma pitati njene građane što oni misle po tom pitanju.

5 Ibid.
Paradžik je naglašavao da "ako se $\mathrm{BiH}$ ne želi pripojiti Hrvatskoj, tad će se Hrvatska pripojiti Bosni i Hercegovini kako bi se sve naše zemlje našle u Hrvatskoj. Mi pravaši znamo kome narod iz Bosne i Hercegovine neće, a njihova je slobodna volja da odluče kome hoće" (ibid.: 138139). Smatrao je da je hrvatska istočna granica do Subotice, Zemuna, Drine, Sandžaka i Boke Kotorske koje su hrvatski državni teritorij a "tko sada na tim teritorijima živi, to je druga stvar” (ibid.: 185).

Nakon pravaškog Sabora u priopćenju koje je Paradžik supotpisao ispred HSP-a, žalio se na pojavu "neostaljinizma u Hrvatskoj”. Radilo se o otvorenom pismu glavnom ravnatelju Hrvatske radio-televizije Antunu Vrdoljaku u kojemu je izraženo nezadovoljstvo zbog sustavne medijske izolacije stranke i (ne) prikazivanja njena rada. Paradžik Hrvatsku radio-televiziju naziva "zagrebačkom Bastiljom”. Za HSP kaže Paradžik da je "druga strana u odnosu na HDZ, koju gospoda smatraju marginalnom strankom, kao što je i Slobodan Milošević jednako tako mislio u odnosu na srbijansku opoziciju (...) HSP ne razlikuje fašizam od komunizma, jer su i jedan $\mathrm{i}$ drugi unesrećili hrvatski, kao i mnoge narode svijeta, ali između njih ipak postoji jedna razlika, a to je što su fašisti progonili i ubijali na ovim prostorima četiri godine a komunisti 44" (ibid.: 194). Tijekom 1991. politička je kriza u SFRJ bila na vrhuncu. Srpski blok u Predsjedništvu SFRJ, ojačan strogo nadziranim marionetskim predstavnicima Crne Gore, Kosova i Vojvodine odbio je da izabere hrvatskog predstavnika Stjepana Mesića za predsjednika Predsjedništva SFRJ na način utvrđen Ustavom i Poslovnikom, koji je do tada poštivan 11 puta. Paradžik komentirajući takvu odluku izjavio je kako "HSP uopće ne zani- 
ma Mesićev izbor, jer mi ne priznajemo niti jednu savezni instituciju - pa tako ni Predsjedništvo. Borimo se za slobodnu i demokratsku Hrvatsku, te nas zanima samo tko će biti predsjednik Hrvatske" (ibid.: 214). Nakon uspostave demokratske vlasti putem višestranačkih izbora, Hrvatska je, u nastojanju da razborito riješi proces dezintegracije jugoslavenske federacije mirnim sredstvima, zajedno sa Slovenijom, ponudila ostalim republikama preobrazbu centralizirane federacije u konfederaciju, savez suverenih država, po uzoru na institucije Europske ekonomske zajednice, što je srpski blok odbio jer je inzistirao na federaciji kao jedinstvenoj državi. Srbija i JNA su prijetile državnim udarom i neustavnom uporabom sile protiv nepokorenih republika. Pravaški idealizam i radikalizam nije trpio i podržavao taktiku hrvatskih vlasti koja nije imala hrabrosti da jasno i na jednostavan način postavi referendumsko pitanje u samostalnosti Hrvatske. HSP je u međuvremenu organizirala potpisivanje peticije za samostalnu hrvatsku državu a Paradžik je rekao da će kada skupe milijun potpisa s time upoznati domaću i svjetsku javnost, Saboru poslati zahtjev da proglasi samostalnu državu a "ako Sabor to ne učini, proglasiti će je HSP" (ibid.: 215) To je i rezultiralo Lipanjskom poveljom koju su Paraga i Paradžik u ime Predsjedništva HSP-a donijeli 13. lipnja 1991. u hotelu "Bigeste" u Ljubuškom kojom su pozivali "sve Hrvatice i Hrvate, Muslimane, Sandžaklije, graničare s Drine, hrvatske državotvorne stranke, pokrete i organizacije, kao i sve one građane koji Hrvatsku priznaju za svoju domovinu da se pridruže svojim potpisima obnovi i uspostavi nezavisne države Hrvatske na cjelokupnom povijesnom i etničkom prostoru sa istočnim granicama Subotica, Zemun, Drina, Sandžak i Boka Ko- torska" (ibid.: 222). Lipanjska povelja označila je za HSP zapravo uspostavu hrvatske države na povijesnom i prirodnom pravu, što nije moralo biti podudarno s idejom obnove NDH koja u svom sastavu nije imala Suboticu i Boku Kotorsku. Riječju, radilo se o maksimalističkom programu. Uz ogradu od fašističkog karaktera Pavelićeve $\mathrm{NDH}$, Paraga je donošenje Lipanjske povelje argumentirao rasprodajom hrvatskog teritorija od strane hrvatske Vlade i utvrđivanjem granica Hrvatske koje moraju biti od Sutle do Drine (Večernji list, 19.6. 1991). Međutim, i kao takva, akcija Predsjedništva HSP-a s donošenjem Lipanjske povelje je prema Ivi Lučiću u Hercegovini "kod lokalnih vlasti i naroda shvaćena kao provokacija i protuhrvatsko nastojanje koje se ne može dovesti u vezu s hrvatskom državnom politikom" (Lučić, 2005: 57). Bez obzira na namjere Predsjedništva HSP-a, predstava u Ljubuškom poslužila je kako ističe Ivo Lučić protuhrvatskoj propagandi koja je svaki politički oblik hrvatstva, a napose predviđeno proglašenje neovisnosti Republike Hrvatske, poistovjećivala s ustaštvom i obnovom NDH (Lučić, 2008: 125). Međutim, na taj događaj od kojeg je vodstvo HSP-a puno više očekivalo, brzo se zaboravilo zbog izbijanja rata u Hrvatskoj (Bošnjak, 2007: 20).

Nakon oružanog sukoba u Borovu Selu 2. svibnja 1991., u kojem je ubijeno 12 hrvatskih policajaca, Paradžik komentirajući taj događaj ustvrdio je da "HSP kao opozicijska stranka nije u mogućnosti osnivanja oružanih odreda ili neke posebne policije, odnosno garde. Međutim, kao najhrvatskija od svih hrvatskih stranaka spremni smo kao građani Republike Hrvatske svim sredstvima braniti njezin suverenitet kao i sve Hrvate ako je to potrebno. Pravaši će 
danas, kao i nekad, tako i ubuduće, uvijek biti na braniku domovine, ne žaleći dati i vlastiti život za njezinu slobodu. Smatram da stranka na vlasti HDZ, Hrvatski sabor i Vrhovništvo, nisu ostvarili skoro ništa od onoga što je obećano u predizbornoj kampanji; nije se dogodilo proglašenje samostalne države Hrvatske, već su se dogodili Knin, Plitivice, Borovo Selo i na kraju kapitulacija" (Paraga i Paradžik, 1991: 215). Dobroslav Paraga je nakon izbijanja sukoba u Sloveniji zatražio od hrvatskih vlasti "da odmah provedu opću mobilizaciju svih za oružanu borbu sposobnih osoba i da se isti odmah upute u Sloveniju kako bi pomogli nastojanja slovenskog naroda u suzbijanju velikosrpske agresije". ${ }^{-}$Takve izjave nesumnjivo su upozoravale da HSP sprema odgovor na velikosrpsku agresiju na hrvatsku i slovensku nezavisnost koja je proglašena 25. lipnja 1991. godine. To je rezultiralo stvaranjem Hrvatskog obrambenog saveza, paravojnih snaga koje je organizirala HSP radi obrane Slovenije i Hrvatske. Ubrzo je taj savez preimenovan u Hrvatske obrambene snage (HOS). "Mi u HSP-u prestajemo biti samo političari i postajemo vojnici. Izvršili smo pripreme za obranu Hrvatske i hrvatskog naroda i svjetska i domaća javnost uskoro će se uvjeriti u našu snagu" izjavili su Paraga i Paradžik na konferenciji za novinare HSP održane 18. srpnja 1991. u Zagrebu naglasivši kako je HOS "nastao spontano od njihovog članstva koji se već bore u prvim borbenim redovima u kriznim područjima Hrvatske" (Večernji list, 19. 7. 1991). Ispočetka je to bio savez za obranu Slovenije a sam naziv za dragovoljačke postrojbe HSP-a osmislio je Paradžik koji

6 PHSP: “Zahtjev Hrvatskom saboru, Vladi, predsjedniku Republike dr. Franji Tuđmanu, domaćoj i svjetskoj javnosti”, Zagreb 27. lipnja 1991. je bio prvi načelnik Ratnog stožera HOS-a dok je Paraga bio vrhovni zapovjednik koji je izjavio "da prestaju biti samo političari i da postaju vojnici" a Paradžik da "osuđuju pregovaranje sa Miloševićem oko hrvatskih teritorija i da ne priznaju podjelu $\mathrm{BiH}^{\prime \prime}$ (ibid.). Riječju, HOS je bio paravojna formacija koju je organizirala HSP izvan vojne ili policijske organizacije s ciljem obrane od velikosrpske agresije (Veselinović, 2014: 69). Obilježavanjem 10. travnja i osnivanjem HOS-a čija je kratica u Drugom svjetskom ratu označavala naziv za oružane snage NDH - Hrvatske oružane snage, jasno pokazuje da je ustašonostalgija bila nazočna u stranačkoj identifikaciji i propagandi HSP-a. Unatoč radikalizmu i ustašonostalgiji pripadnicima HOS-a dok su bili pod ustrojem HSP-a ne može se odreći "da nisu bili hrabri ratnici, kao ni činjenica da se uz njih ne vezuje nijedan ratni zločin" (Goldstein, 2011: 13)

HOS je bio mješovitog sastava u kojem su pored Hrvata koji su činili većinu bili Muslimani, Srbi i Albanci te po nekoliko desetaka stranih dragovoljaca iz Velike Britanije, Irske, Nizozemske i Francuske. Paradžik je naveo kako je HSP postrojbe HOS-a sama opremila, od uniformi do raznovrsnog modernog oružja zahvaljujući sredstvima "koje im je omogućio Hrvatski potporni i obrambeni fond 'Drina', iz Toronta u Kanadi', te da "jedinice djeluju kao desetice, tridesetice, stotice, ili dvjestotice, što je vrlo slično rimskom sistemu vojske po centurijama i kohortama" (Butković i Grakalić, 1992: 39). Paradžik je kao načelnik Ratnog stožera HOS-a imao političku funkciju, idejno političko djelovanje i bio je zadužen za novačenje i logističku potporu. Na terenu je radio pripremu, obuku i upućivanje ljudstva na teren. Nakon sastanka vodstva HSP-a s predsjednicima Albanije i Bugarske usvojen 
je nacrt povelje o stvaranju Antihegemonističke (antivelikosrpske) koalicije pokreta i stranaka Hrvata, Albanaca i Bugara, čiji je naum Srbiju svesti na prirodne granice iz 1912. (Večernji list, 19. 7. 1991, Večernji list, 9. 7. 1991).

Paradžik i Paraga smatrali su da hrvatske vlasti oklijevaju pred opasnošću dobro pripremane velikosrpske agresije koja zapravo već traje. Prve specijalističke obuke pripadnika HOS-a vršene su u općini Kočevje u Sloveniji, dogovorom slovenskog ministra obrane Janeza Janše i Jože Pučnika s jedne strane i Parage i Paradžika s druge koji su stavili na raspolaganje pripadnike HOS-a Teritorijalnoj obrani Slovenije u slučaju napada JNA na slovensku nezavisnost. U specijalističkoj obuci sudjelovali su pripadnici slovenske specijalne brigade Moris, dok je za logistiku bilo zaduženo Ministarstvo obrane Republike Slovenije (Praznik, 2007: 41-44). Nakon osnivanja i organiziranja HOS-a, glavni tajnik HSP-a i urednik Hrvatskog prava Krešimir Pavelić napustio je stranku zato jer se suprotstavljao ustrojavanju takvih stranačkih vojnih postrojbi "jer bi se takav čin protivio pravnom poretku i ujedno bi bio usmjeren protiv hrvatskih nacionalnih interesa" (Pavelić, 2003: 74). Osuda organiziranja HOS-a posebno je bila vidljiva u istupima Franje Tuđmana koji je smatrao kako je Paraga organiziranjem HOS-a "pokušao uskrsnuti kriptofašističke tendencije" a da su se pripadnici HOS-a "u početku rata kao dragovoljci javili za borbu protiv Armije i srpskih ekstremista. Kasnije nismo mogli u potpunosti provesti njihovo uvrštavanje u svoje redovite postrojbe. Oni su željeli kompromitirati našu demokraciju i srušiti demokratsku vlast” (Tuđman, 1999: 190, 227). Paraga i Paradžik su u ime HSP-a 18. ožujka 1991. službenim podneskom u Saboru gdje su bili primljeni kod predsjednika Žarka Domlja- na zahtijevali povratak u posjed zgrade Starčevićevog doma, ali taj objekt nikada nije vraćen (Hrvatsko pravo br. 4-5, 1991). Vidjevši da od povratka neće biti ništa, HOS je 18. rujna 1991. zauzeo Starčevićev dom. Tim je djelom HSP sa dragovoljcima HOS-a povratila u posjed zgradu koja je podignuta 1895. u vremenu nastupa modernog pravaštva u čast Ante Starčevića radi poticanja šire nacionalne svijesti o Ocu Domovine, te je ujedno zgrada postala središnjica HSP-a kao i Ratni stožer HOS-a.

\section{Ubojstvo Ante Paradžika}

Paradžik je ubijen 21. rujna 1991. od strane hrvatske policije na blokadnom punktu "Jež 2" u Sesvetama. Te je večeri Paradžik održao govor na tribini svoje stranke u Hrvatskom domu u Križevcima (Rohaček, 2009: 13). U ratu koji već uvelike traje u raznim dijelovima $\mathrm{Hr}$ vatske njegova je pravaška retorika bila predvidljiva: pozivao je da se Hrvatska oslobodi jugoslavenskog jarma i uvjeravao je stotinjak građana i simpatizera da poslušaju Tuđmana ako ih pozove na sveopći ustanak, iako ga je bio označio kao kolebljivca. Govoreći o programu HSP-a, Paradžik je naglasio da je to najhrvatskija i najstarija hrvatska stranka čiji su članovi bili najveći hrvatski rodoljubi, a tadašnju hrvatsku vlast Paradžik je "nazvao komunističkom i boljševičko - generalskom, optuživši da je većina ministara u hrvatskoj Vladi radila za KOS i UDB-u. Tko je god bio veći komunist, udbaš, kosovac, dobio je kod nas ministarsko mjesto", rekao je Paradžik na križevačkoj tribini pozvavši narod "da se osvijesti uz povijesno pomirenje nekadašnjih ustaša, domobrana i partizana" (Vjesnik, 23. 9. 1991). Tribina na kojoj je Paradžikov tjelohranitelj skočio među publiku s automatom na gotovs, potraja- 
la je do devet sati navečer i Paradžik se tad zaputio u Zagreb s tajnikom HSP-a iz Toronta Ivanom Oršanićem. Ladom nivom upravljao je Branko Perković. Cesta do Zagreba bila je zamračena zbog zračne opasnosti. Prilikom dolaska u Zagreb, policajci na blokadnoj točki "Jež 2" dobili su dojavu od policajca Blaža Sarića kako se u Ladi nivi nalaze sumnjive osobe koje treba provjeriti. Sumnjivci su, glasila je dojava, najvjerojatnije bili "martićevci". Da bi neprijateljske snage došle iz smjera Križevaca za tako nešto nije bilo ni mogućnosti. Ni danas nije jasno zbog čega je Sarić to rekao, budući da je upravo on prethodno zaustavio Ladu nivu na blokadnom punkta "Drava 778 ” i razgovarao s vozačem Perkovićem (Gaura, 2010).

Malo prije 23 sata, prilikom dolaska na punkt, Lada se zaustavila na signale policijske ekipe u kojoj su bili Željko Vučemilović Grgić, Branko Matošević, Željko Čeko i Paško Palić. No, prema tvrdnjama policajaca, tada se začuo pucanj. Jedan policajac prišao je vozilu, a onda se udaljio nekoliko koraka, repetirao kalašnjikov i bez upozorenja ili provjere otpočeo s nemilosrdnom vatrom. Pridružili su mu se i ostali policajci. Paradžika je pogodio jedan jedini metak koji je bio koban: pogodio ga je u slabinu, oštetio jetru i probio plućno krilo. Gotovo istog trenutka Paradžik je preminuo, Perković je zadobio prostrijelnu ranu desne ruke, a Oršanić je nekim čudom ostao neokrznut. Što se policajaca tiče, jedan od njih pogođen je u desnu natkoljenicu. Očevid ubojstva vodio je dežurni istražni sudac zagrebačkog Okružnog suda Branko Čižmek. Na mjestu događaja zatekao je Ladu na kojoj su sve gume bile izbušene, a u njoj su

7 To je eponim koji su mediji dodijelili specijalnim postrojbama milicije tzv. "SAO Krajine". se nalazila automatska puška i pištolj CZ 7,62 mm. Tridesetak rupa na karoseriji bilo je raspoređeno sa svih strana. Od stakala preživjelo je samo zadnje desno. Oko Lade na tlu je pronađeno pedesetak čahura, a u samom vozilu ostale su krhotine streljiva (Večernji list, 23. 9. 1991). Balističkim vještačenjem nepobitno je utvrđeno da iz oružja pronađenog u Ladi nije pucano (Gaura 2010).

Policajci su kasnije tvrdili da se automobil nije zaustavio ni na njihovom, ni na punktu prije "Ježa 2", no Dobroslav Paraga tvrdio je da se Lada od Križevaca do Sesveta na policijskim kontrolama zaustavila pet puta što je potvrđeno i sigurnosnom provjerom. Prema svjedočenju Oršanića, automobil se na punktu “Jež 2" zaustavio na policijski signal nakon čega je jedan policajac prišao automobilu s vozačeve strane, ali nije zatražio dokumente, nego se odmah udaljio nekoliko koraka unatrag i zapucao $(J u$ tarnji list, 18. 11. 2001). Sudac Okružnog suda u Zagrebu Branko Šerić osudio je četvorku 13. listopada 1993. za ubojstvo s predumišljajem. Prvooptuženi Vučemilović Grgić osuđen je na sedam godina zatvora, drugooptuženi Matošević na šest godina, trećeoptuženi Čeko na pet godina i deset mjeseci te četvrtooptuženi Palić na pet godina i osam mjeseci zatvora. ${ }^{8}$ Paradžik je sahranjen 25. rujna

8 OP obitelji Ante Paradžika: Presuda Okružnog suda u Zagrebu, broj: K-190/93 od 13. listopada 1993. godine, 4. Treba istaknuti da se radilo o ponovljenom sudskom postupku. Prema prvoj presudi Okružnog suda u Zagrebu jedino je Željko Vučemilović Grgić proglašen krivim i osuđen je na četiri godine zatvora dok su ostali oslobođeni. OP obitelji Ante Paradžika: Presuda Okružnog suda u Zagrebu, broj: VII-K-279/91-143. od 4. prosinca 1992. godine. Nakon žalbe državnog odvjetništva Vrhovnom sudu, ukinuta je presuda, a predmet je vraćen na ponovno suđenje pred novim sudskim vijećem. 
1991. na zagrebačkom groblju Mirogoj pred dvadesetak tisuća ljudi. Ostavio je iza sebe suprugu Jozefinu i troje djece, Mislava, Veroniku i Katarinu. Na Paradžikovom pogrebu, Dražen Budiša istaknuo je da "u ovom trenutku mi ne znamo da je Antina smrt stjecaj tužnih, nesretnih okolnosti u ovom olovnom vremenu ili se radi o političkom ubojstvu", dok je Dobroslav Paraga naglasio "da će svaki Hrvat biti sljedbenik Ante Paradžika, hrvatskoga junaka i hrvatskoga vojnika". ${ }^{10}$

Osuđeni policajci podnijeli su ustavnu tužbu jer su smatrali da su im osporenom presudom Vrhovnog suda Republike Hrvatske, kao i osporenom prvostupanjskom presudom, povrijeđena ustavna prava. Osnovanost ustavnih tužbi posebice nalaze u činjenici da su sudovi u njihovom slučaju odbili primijeniti odredbu članka 1. stavka 1. tada važećeg Zakona o oprostu od krivičnog progona i postupka za krivična djela počinjena $\mathrm{u}$ oružanim sukobima i u ratu protiv Republike Hrvatske. Tom je odredbom bilo propisano da će se obustaviti kazneni progon, odnosno kazneni postupak protiv počinitelja kaznenih djela počinjenih u oružanim sukobima, $\mathrm{u}$ ratu protiv Republike Hrvatske ili u svezi s tim sukobima, odnosno ratom, ako su počinjena u razdoblju od 17 . kolovoza 1990. do 25. rujna 1992. godine. Za ta djela kazneni progon se neće poduzimati, a kazneni postupak se neće pokretati. Glede (ne)primjene navedenog Zakona o oprostu, u kaznenom predmetu, sudovi su u osporenim presudama zauzeli sljedeća stajališta: Okružni sud u Zagrebu, presuda od 13. listopada 1993.: "Sud

9 OP obitelji Ante Paradžika: TV Dnevnik, Hrvatska televizija, Zagreb, 25. rujna 1991. VHS kazeta.

10 Ibid. nije primijenio Zakon o oprostu od krivičnog progona i postupka za krivična djela počinjena u oružanim sukobima i u ratu protiv Republike Hrvatske (NN 58/92) s obzirom na činjenicu da kritične večeri 21. rujna 1991. godine na blokadnom punktu 'J. 2'11 nije došlo do nikakvog oružanog sukoba, a što je osnovni uvjet da bi se protiv počinitelja krivičnih djela i to upravo I, II, III i IV optuženika mogao primijeniti isti Zakon o oprostu". ${ }^{12}$ Vrhovni sud Republike Hrvatske, presudom od 23. veljače 1994., zauzima stav: "Nisu u pravu optuženi V. G. Z. ${ }^{13}$ i P. P. ${ }^{14}$ kada tvrde da je trebalo obustaviti postupak na temelju Zakona o oprostu (...) Oprost se može priznati samo za krivična djela koja su u neposrednoj svezi s ratnim operacijama, vojnom službom i sl., a ne i za krivična djela učinjena uz prekoračenje službenih ovlaštenja pripadnika policije". ${ }^{15}$ Ustavni sud Republike Hrvatske utvrdio je da podnositeljima ustavnih tužbi u konkretnom slučaju nije povrijeđeno ustavno pravo na slobodu "budući da im je sloboda oduzeta u zakonom propisanom slučaju i sukladno postupovnim pravilima mjerodavnog propisa i prihvaća stajalište Vrhovnog suda izraženo u osporenoj presudi". ${ }^{16}$ Međutim, Franjo Tuđman je 8. rujna 1994. donio Odluku kojom je pomilovao osuđene policajce koji

11 Jež 2.

12 OP obitelji Ante Paradžika: Presuda Okružnog suda u Zagrebu, broj: K-190/93 od 13 . listopada 1993. godine, 35.

13 Vučemilović Grgić Željko.

14 Palić Paško.

15 OP obitelji Ante Paradžika: Presuda Vrhovnog suda Republike Hrvatske, broj: Kž21/94 od 23. veljače 1994. godine.

16 OP obitelji Ante Paradžika: Odluka Ustavnog suda Republike Hrvatske, U-III / 492 / 1994. 
su ubrzo nakon toga otpušteni s izdržavanja kazni, te je jedan od atentatora poslije predavao na Policijskoj akademiji u Zagrebu, a svi "su vraćeni na posao u hrvatsku policiju, iako je to u izravnoj suprotnosti sa zakonom" (Jurčević, 2013: 261). Sudac Branko Šerić nakon takve odluke odlučio je potražiti posao u odvjetničkoj profesiji. Ante Miličević, odvjetnik obitelji Paradžik je u svibnju 1998. zatražio istragu protiv Blaža Sarića koji je u noći ubojstva kontrolnom punktu dojavio da se u automobilu u kojem se vozio Paradžik možda nalaze "martićevci", međutim prilikom istrage protiv Sarića tijekom 1998. ništa bitno nije postignuto u smislu rasvjetljavanja ubojstva te se cijeli slučaj nije pomakao s mjesta, odnosno Vrhovni je sud odbio žalbu kao neosnovanu. Kako piše Ivica Buljan “o sumnjivoj ulozi Sarića govore i informacije iz tadašnjih hrvatskih obavještajnih krugova po kojima je Paradžika cijelo vrijeme, a posebno taj dan, pratio odjel tajne pratnje MUP-a (...) a vrlo raširena bila je i verzija po kojoj su Paradžika zajednički likvidirali hrvatska vlast i pripadnici KOS-a, koji su u to vrijeme zauzimali čelna mjesta u MUP-u i SZUP-u, a kasnije je veći dio njih bio uhićen kao članovi špijunske skupine Labrador" (Jutarnji list, 19. 11. 2001). Slučaj je ponovno medijski aktualiziran 2001. kada je Paraga zatražio reviziju postupka ili otvaranja novog postupka za ubojstvo Paradžika. Paraga je iznio tvrdnje da je od Ruže Tomašić, povratnice iz Kanade i članice HSP-a koja je 1991. radila kao voditeljica Tuđmanovog osiguranja u Banskim dvorima dobio informacije pred svjedocima "da je Tuđman donio odluku” da se likvidiraju on i Paradžik, te da o tome postoji dokumentacija koju je 2001. predao Državnom odvjetništvu (Vjesnik, 1. 2. 2005). Zbog bolesti Tomašić se 1992 . vratila u
Kanadu i nije bila dostupna hrvatskom pravosuđu tijekom suđenja policajcima za ubojstvo Paradžika. Tek 2005. na Paragine tvrdnje je Tomašić, povratnica iz Kanade po drugi puta, izjavila da je Paradžikovo ubojstvo najviše odgovaralo Paragi, “jer se predsjednik Tuđman slagao s Paradžikom, ali s Paragom nije". ${ }^{17}$ Nakon toga je Paraga pozvao Tomašić u policiju na poligrafsko ispitivanje na koje se ona nije odazvala pa ju je Paraga optužio da je notorna lažljivica i da je "zbog ovakvih laži, spreman ići do kraja. Do kraja zbog istine i dostojanstva Ante Paradžika" (Vjesnik, 1. 2. 2005). Kontroverza oko pitanja je li za ubojstvo Paradžika krivnju snosi državni vrh prenijela se iz političkog života i u znanstvenoistraživački. Prema Josipu Jurčeviću radilo se o tipičnom primjeru politički motiviranog ubojstva jer je Paradžik bio praćena osoba, ubijen je u "sačekuši", poznat je identitet atentatora, međutim "kreatori i nalogodavci su ostali sakriveni” (Jurčević, 2013: 252-264). S druge strane, Dragutin Lalović u svojoj analizi procesa konstitucije hrvatske države eksplicitno navodi da je "HDZ ubio Paradžika” (Lalović, 2001: 19) a da nije tu tvrdnju podupro sa kakvim konkretnim dokazima. U svakom slučaju ubojstvo Paradžika bio je udarac za HSP.

\section{Zaključak}

Iako je prošlo četvrt stoljeća od smrtonosnog atentata na Antu Paradžika, hrvatska historiografija prešućuje ulogu koju je Paradžik odigrao u događajima iz 1971. i 1991. godine. To je jedna od najprogonjenijih osoba nakon Karađorđeva 1971. godine. Ukupno je Paradžik

17 PHSP: Nedjeljom $u$ dva (gost: Ruža Tomašić), urednik Aleksandar Stanković, Hrvatska radio televizija, Zagreb, 30. siječnja 2005. 
proveo u zatvoru tri godine, šest mjeseci i osam dana, a bez putovnice bio je punih 19 godina. Za vrijeme Hrvatskog proljeća kao predsjednik SSH Paradžik je u svojim nastupima težio za što većom samostalnošću Hrvatske u Jugoslaviji. Možda je i to bio jedan od razloga zašto je toliko bio proganjan. Štrajk kojeg su poveli hrvatski sveučilištarci predvođeni Paradžikom iako tada nije ostvario nijedan zacrtani cilj pokazao je snagu, brojnost, organiziranost i discipliniranost studentskoga pokreta. U Hrvatskoj nikada više nije bilo studentskog štrajka kao onog iz 1971., a studenti danas u Hrvatskoj nisu neki veći politički faktor kakav su bili te 1971. godine. Međutim, ono što je Paradžik najviše želio i za što se zalagao bila je hrvatska državna nezavisnost, a upravo je HSP koju je obnovio bila prva stranka koja je u svom programu imala za cilj nezavisnost Hrvatske, ali izvan njezinih republičkih granica. Kao sljedbenici Starčevićeve i Kvaternikove izvorne pravaške ideologije, Paradžik i HSP nikome nisu priznavali dosljedniju državotvornost od one što je sami ispovijedaju. Nezavisna nacionalna država za Paradžika je bila najveća vrijednost. Obilježavanje 10. travnja devedesetih godina za Paradžika nije nužno značilo slaviti fašizam i političko-ideološki karakter NDH nego obilježiti sjećanje na osnivanje jedne hrvatske države. Paradžik je jasno osuđivao represivni ustaški režim i njegove zločina, argumentirajući da je ustaški režim imao fašistički i totalitarni karakter a ne država. $\mathrm{NDH}$ nije želio poistovjećivati sa režimom nego je smatrao da ga je trebalo promijeniti. Unatoč tome treba istaknuti da je u Paradžikovom djelovanju, a to znači i u vodstvu HSP-a bila nazočna ustašonostalgija koja je bila vidljiva $u$ komemoracijama 10. travnja, korištenju termina NDH, osnivanju HOS-a čija je kratica bila istovjetna onoj u oružanim snagama NDH, a i neke su postrojbe nosile nazive po ustaškim generalima (Rafael Boban, Jure Francetić), kao i činjenica da su ogranci HSP-a u Australiji i Kutini nosili ime po Anti Paveliću. Uostalom i sam je Paradžik imao obiteljsko naslijeđe povezano s NDH stoga takva identifikacija i ne čudi. HSP se deklarirala kao stranka s najžešćim nabojem antijugoslavenstva i antikomunizma. Paradžikovi politički govori bili su radikalni, međutim nije pozivao na progone i zatiranja, nije dopuštao zlostavljanja i kršenja prava čovjeka i naroda. Paradžik je ubijen 11 dana nakon što je zajedno $s$ Dobroslavom Paragom na skupu HSP-a u Zagrebu na Trgu bana Josipa Jelačića javnosti prvi put predstavljen HOS, stranačke paravojne dragovoljačke postrojbe koje su pravaši sami organizirali u vrijeme dok Hrvatska vojska još nije bila posve formirana. Svojim djelovanjem HSP je okarakterizirana kao opasna za državni poredak i kao velika konkurencija vladajućem HDZ-u. HSP je pod Paraginim i Paradžikovim vodstvom bila najžešći kritičar politike Tuđmana i HDZ-a. Na takvo djelovanje HSP-a, vladajući režim odgovorio je represijom, a Paradžik je bio prva žrtva koja je označila početak kraja HSP-a. Formalno, za ubojstvo Paradžika krivci su osuđeni na zatvorske kazne, međutim kazne nisu izdržali u cijelosti što im je svojim pomilovanjem omogućio prvi hrvatski predsjednik Franjo Tuđman i ubrzo nakon toga svi su vraćeni natrag na posao u policiji. Taj slučaj je imao sudski epilog, ali navedene činjenice jasno upućuju na to da sud nije išao u ispitivanje svih okolnosti tog ubojstva niti u traženje pozadine onog što se dogodilo. Slučaj je zauvijek pao u zakonski zaborav budući da je nakon 20 godina nastupila zastara i više nitko, barem ne pred pravosuđem, 
neće moći odgovarati za ono što se 21 . rujna 1991. oko 22 sata dogodilo na blokadnom punktu “Jež 2" u Sesvetama. Ulice koje nose Paradžikovo ime nalaze se u Osijeku i Kninu, dok se u Zagrebu njegovo ime nalazi u Fondu imena ulica što ga vodi Gradski zavod za katastar i geodetske poslove i čim se nađe lokacija Odbor za imenovanje naselja, ulica i trgova predložit će Gradskoj skupštini Grada Zagreba da njegovim imenom nazove ulicu ili neku drugu neimenovanu javnu površinu na području Grada Zagreba. Sveti cilj pravaštva ostvaren je,

\section{LITERATURA}

\section{Arhivski izvori}

Osobna pismohrana (OP) obitelji Ante Paradžika

Pismohrana Hrvatske stranke prava (PHSP)

\section{Knjige i članci}

Barić, N. (2005) Srpska pobuna u Hrvatskoj: 1990.-1995. Zagreb: Golden marketing - Tehnička knjiga.

Bilandžić, D. (1999) Hrvatska moderna povijest. Zagreb: Golden marketing Tehnička knjiga.

Bilandžić, D. (2001) Propast Jugoslavije i stvaranje moderne Hrvatske: eseji, članci, interviewi, analize, izvješća, izjave. Zagreb: AGM.

Blažeković, G. A. (2007) Hrvatska stranka prava 1990. godine: Obnova, djelovanje i uzroci raskola, U: Jasna Turkalj, Zlatko Matijević i Stjepan Matković (ur.) Pravaška misao i politika: zbornik radova, (str. 301-317). Zagreb: Hrvatski institut za povijest. stvorena je nezavisna nacionalna država, a Paradžik je kao suvremeni pravaš to i dočekao. Neosporne su i Paradžikove zasluge za stvaranje i obranu države kroz organiziranje HOS-a, a njegova djelatnost od 1971. jasno mu daje za pravo na mjesto među osobama koje su obilježile suvremenu hrvatsku političku povijest. Paradžik je posmrtno 1995. od predsjednika Tuđmana odlikovan Redom Stjepana Radića za zasluge i stradanje u borbi za nacionalna i socijalna prava i razvitak hrvatskog naroda a priznat mu je i status hrvatskog branitelja.
Bošnjak, M. (2007) Blaž Kraljević - pukovnik i pokojnik. Mostar: Radio Stari most

Butković, D.; Grakalić, M. (1992) Domovinski rat: interview. Zagreb: Azur journal.

Dabčević-Kučar, S.; Gotovac, D.; Budiša, D. (1996) Nakon četvrt stoljeća. Erasmus (15): 9-22.

Dabčević-Kučar, S. (1997) '71: hrvatski snovi i stvarnost. Knjiga 2. Zagreb: Interpublic.

Dunatov, Š. (2010) Začetci višestranačja u Hrvatskoj 1989. godine. Radovi Zavoda za povijesne znanosti HAZU u Zadru. 52: 381-397.

Gaura, O. (2010) Ljudi koje je 90-ih trebalo ukloniti. Nacional br. 741. http:// www.nacional.hr/clanak/76462/ljudikoje-je-90-ih-trebalo-ukloniti pogledano: 10. 2. 2016.

Gaura Hodak, O. (2015) Eksluzivno: službeni popis 820 ljudi koje je obrađivala Udba. Nacional br. 897. http://www. nacional.hr/sluzbeni-popis-820-lju- 
di-koje-je-obradivala-udba/, pogledano: 15. 4. 2016.

Goldstein, I. (2011) Povijest Hrvatske 1945-2011. 3. svezak. 1991-2011. Zagreb: $\mathrm{EPH}$

Gross, M. (2000) Izvorno pravaštvo: ideologija, agitacija, pokret. Zagreb: Golden marketing.

Hitrec, H. (1992) Lijepa moja. Zagreb: Azur journal.

Izvještaj o kontroli zakonitosti rada Matice hrvatske (2002) Zagreb: Matica hrvatska

Jurčević, J. (2013) Slučaj Perković: spašavanje zločinačke budućnosti. Zagreb: Dokumentacijsko informacijsko središte, Hrvatsko žrtvoslovno društvo.

Knezović, M. (1995) Štrajk hrvatskih sveučilištaraca u jesen 1971. u onodobnom tisku. Radovi Zavoda za hrvatsku povijest 28(1): 230-241.

Knežević, D. (2015) Hrvatska demokratska zajednica od osnivanja do raskida s Jugoslavijom, doktorska disertacija Sveučilišta u Zagrebu.

Lalović, D. (2001) Hrvatska Druga republika i njezine državotvorne kušnje. Politička misao, 38(1): 12-25.

Lučić, I. (2005) Ima li Hercegovine? (Tko i zašto negira Hercegovinu i Hercegovce?). National security and the future, 6(3-4): 37-86.

Lučić, I. (2008) Bosna i Hercegovina od prvih izbora do međunarodnog priznanja. Časopis za suvremenu povijest, 40(1): 107-140.

Matković, H. (1999) Povijest Hrvatske seljačke stranke. Zagreb: Naklada Pavičić

Paraga, D.; Paradžik, A. (1991) Borba za hrvatsku državnu nezavisnost - od obnove do Lipanjske povelje Hrvatske stranke prava. Zagreb: HSP

Paraga, D. (1995) Goli otok - istočni grijeh Zapada. Zagreb: Vlastita naklada
Pavelić, K. (1995) HSP od obnove do slobode: politikanti, karijeristi, demagozi, pseudopravaši, masoni i kosovci. Zagreb: HDSP.

Pavelić, K. (2003) Hrvatski herostrati. Zagreb: Hrvatski pravaški pokret.

Pavković, M. (1991) Hrvatski mučenici. Koprivnica: Glas Podravine.

Perić, I. (gl. ur.) (2007) Povijest Hrvata Od 1918. do danas. Knjiga 3. Zagreb: Školska knjiga.

Ponoš, T. (2007) Na rubu revolucije - studenti '71. Zagreb: Profil International

Praznik, B. (2007) Trgovci s smrtjo. Branilci domovine II. Ljubljana: Vlastita naklada.

Rohaček, G. (2009) Hrvatsko pravaštvo na prijelazu tisućljeća. Čakovec: Vlastita naklada

Spehnjak, K.; Cipek, T. (2007.) Disidenti, opozicija i otpor - Hrvatska i Jugoslavija 1945. - 1990. Časopis za suvremenu povijest, 39(2): 255-297.

Šošić, H. (1993) Hrvatski politički leksikon, Prvi i Drugi dio. Rijeka: Tiskara Rijeka.

Tomac, Z. (2012) Memoari. Zagreb: Tkanica.

Tuđman, F. (1999) Hrvatska riječ svijetu: razgovori sa stranim predstavnicima. Zagreb: Hrvatska sveučilišna naklada, Hrvatski institut za povijest.

Veselinović, V. (2014) Obnavljanje i djelovanje Hrvatske stranke prava, 1990 1992. Politička misao, 51(2): 55-87.

\section{Novinski izvori}

Hrvatsko pravo

Hrvatsko sveučilište

Jutarnji list

Večernji list

Vjesnik 


\section{The political activites of Ante Paradžik}

SUMMARY The author, on the basis of archive materials, press and literature reconstruct the life and political activity of politician Party Ante Paradžik. During the Croatian Spring Paradžik was elected president of the Union of Croatian students who gathered representatives of all Croatian university centers. As one of the leaders of the student movement of 1971, he was sentenced to three years in prison, which he fully served. With the establishment of the multiparty system in Croatia, Paradžik was a reformer and vice president of the Croatian Party of Right, and the main political goal of the party was an independent state of Croatia. The outbreak of the aggression against Croatia, Paradžik together with Dobroslav Paraga organized volunteer party militiamen called Croatian Defence Forces. He was also vice president of the Croatian Democratic Club of Central Europe and the Secretary General of the Croatian Association of Political Prisoners. He was killed in 1991 under unclear circumstances by members of the Croatian police.

KEYWORDS Ante Paradžik, Croatian Spring, Croatian Party of Right, Croatian Defence Forces, contemporary Croatian political history 